\title{
Conservative Christians' Expectations of Non-Christian Counselors
}

\section{Christine Belaire and J. Scott Young}

In this study of conservative Christians' expectations of counseling, 100 participants rated their expectations of the behaviors and attitudes of a non-Christian counselor. Results suggest that highly religious Christians expected more in-session religious behaviors from a non-Christian counselor than did moderately religious Christians. Both moderately and highly conservative Christians expected a non-Christian counselor to display aftitudes of acceptance and tolerance for Christian beliefs.

indings of research conducted during the last 25 years suggest that an individual's expectations of counseling significantly affect both the process and outcome of counseling. For example, willingness to begin counseling, the depth of the therapeutic work, and length of stay in treatment have all been linked to client expectations of the process (Tinsley, Bowman, \& Barich, 1993; Tinsley, Brown, De St. Aubin, \& Lucek, 1984; Tinsley \& Harris, 1976; Tinsley, Tokar, \& Helwig, 1994; Worthington, 1988; Yanico \& Hardin, 1985). Research has also indicated that many religious clients would like to discuss spiritual and religious issues within the counseling session (Belaire \& Young, 2000; Bergin, 1991; Kroll \& Sheehan, 1989). However, the research also suggested that many mental health practitioners have fewer religious beliefs than does the general population (Bishop, 1992; Grimm, 1994; Kroll \& Sheehan, 1989). For example, in a survey of psychotherapists, Bergin and Jensen (1990) found that only $29 \%$ of the respondents thought that religious issues were important enough to address in counseling. Therefore, a religiosity gap often exists between mental health professionals and clients (Bergin, 1980; Bergin \& Jensen, 1990). Just as other cultural issues do, religious beliefs play an important role in the lives of religious people; they help to shape an individual's worldview (Bishop, 1992; Frame \& Williams, 1996; Pate \& Bondi, 1992; Worthington, 1988) and, according to some researchers, their expectations for counseling (Quackenbos, Privette, \& Klentz, 1985; Worthington, 1990).

Several studies have been conducted to examine the expectations of religious clients about counseling and have produced contradictory results. Guinee and Tracey (1997) compared Christian and non-Christian respondents' ratings of a Christian counselor, a spiritually empathetic counselor, and a secular counselor. The study revealed that highly religious respondents rated the Christian counselor higher on social influence, and the respon-

Christine Belaire is a counselor with Conflict Resolutions in Hammond, Louisiana. J. Scott Young is an associate professor at Mississippi State University, Mississippi State. Correspondence regarding this article should be sent to Christine Belaire, Conflict Resolutions, 105 South Cherry Street, Hammond,
LA 70403 (e-mail: cbelaire@msn.com). 
dents' were more willing to seek help from the Christian counselor. Furthermore, highly religious respondents had more favorable perceptions of the Christian counselor than did the less religious and nonreligious respondents. However, the respondents' levels of religiosity (high or low) did not affect their ratings of the spiritually empathetic or secular counselors. McCullough and Worthington (1995), in a study of clients' expectations of counselors who were described as supporting and challenging or who ignored clients' religious beliefs, found that the religious college student population surveyed desired counselors who supported religion rather than counselors who challenged or ignored religious values.

In contrast to the previously mentioned study, Morrow, Worthington, and McCullough's (1993) study of 102 undergraduate psychology students found that the counselor who supported the client's religion was viewed as less expert, less professional, and less persuasive than the counselors who challenged or ignored religious values. Similarly, Pecnik and Epperson (1985) found that undergraduate Christians expected Christian counselors to be less expert than non-Christian counselors. Although Pecnik and Epperson did not separate respondents by level of conservativeness (low, moderate, high), they reported that Christian respondents showed positive expectations for counseling and positive expectations for the non-Christian counselor, who was seen as more expert and effective.

Godwin and Crouch (1989) replicated Pecnik and Epperson's (1985) study with undergraduate students and found that Christians held more positive expectations of the counselors' attitudes and behaviors than did non-Christians. Furthermore, Godwin and Crouch's findings did not support Pecnik and Epperson's finding that non-Christian counselors were viewed as more expert than the Christian counselor. Rather, Godwin and Crouch found that the Christian counselor was expected to show more religious behaviors, to be more attractive, and to be more accepting than the non-Christian counselor. The differing results of these two studies suggest that Christians may hold expectations about Christian and non-Christian counselors that have yet to be clearly defined.

Overall, the research has suggested that highly religious Christians may hesitate to seek non-Christian counseling or may drop out of treatment early (King, 1978; Larson, Donahue, Lyons, \& Benson, 1989; Lovinger, 1979; Worthington, 1988). Studies on Christians from conservative churches revealed that they were cautious of accepting a referral if they were not certain that the counselor was a Christian counselor (Keating \& Fretz, 1990). J. P. Miller and Eells (1998) suggested that highly religious individuals might lack confidence in professional counselors. Worthington and Scott (1983) concluded that Christians held six negative anticipations about non-Christian counselors. These anticipations are that the counselor would (a) ignore spiritual concerns, (b) treat religious beliefs and experiences as part of the problem, (c) not understand some religious beliefs and concerns, (d) assume that clients share the standards of many nonreligious clients, (e) recommend behaviors or solutions that the client considered immoral, and (f) doubt the usefulness of 
learning from God through prayer and scripture. Using Worthington and Scott's (1983) negative anticipations about counseling, Keating and Fretz (1990) showed that respondents with the strongest religious beliefs had more negative anticipations about counselors, which supported the negative anticipations reported by Worthington and Scott.

Given the research findings that there is a religiosity gap between clients and mental health professionals (Bergin, 1980; Bergin \& Jensen, 1990), along with Worthington and Scott's (1983) negative anticipations about non-Christian counseling, it is not surprising that highly religious Christians have not frequently used non-Christian counseling services. In addition, it is likely that many highly religious Christians seek counseling from clergy. Nevertheless, when problems extend beyond the scope of clergy expertise, it is necessary for the counseling services provided by competent secular counselors to be amenable to highly religious individuals.

Previous research on Christians' expectations about counseling has suffered from several significant limitations. First, data have been obtained primarily from student populations. Second, the research has not generally considered the role of religious commitment. Finally, previous explorations have relied primarily on the Expectations About Counseling Scale, which does not address expectations about the inclusion of religious behaviors by counselors (Godwin \& Crouch, 1989; Guinee \& Tracey, 1997; Keating \& Fretz, 1990; McCullough \& Worthington, 1995; Morrow et al., 1993; Pecnik \& Epperson, 1985; Worthington \& Gascoyne, 1985). Therefore, the purpose of our study was to expand previous research by determining what expectations Christians had regarding non-Christian counseling; the Christians represented various denominations and a wider range of ages and life experiences than had been examined in previous studies (e.g., Guinee \& Tracey, 1997; Keating \& Fretz, 1990; Worthington \& Gascoyne, 1985). We assessed whether Christians expected nonChristian counselors to incorporate religiously supportive techniques into the counseling session. The specific research questions addressed were (a) for a Christian population, is there a relationship between level of religious commitment (low, moderate, high) and expectations of a non-Christian counselor? (b) what are the expectations of Christians regarding the inclusion of religious behaviors in the counseling session by a non-Christian? and (c) what do Christians working with a counselor who is non-Christian expect with regard to the counselor's attitude toward religion in counseling?

\section{Method}

\section{Participants}

Participants in the study were adults over the age of 18 years who were members of churches or religious student organizations in the mid-South region of the United States. The number of participants was 100 , and the mean age of participants was $32(S D=17.07)$, with a range of 18 to 79 years. The distribution of age was positively skewed. Forty-three percent $(n=43)$ 
of the sample were men, and $57 \%(n=57)$ were women. Ethnically, the sample comprised $98 \%$ Caucasians $(n=98)$ and $1 \%$ each of African Americans $(n=$ $1)$ and other $(n=1)$. Of this sample, $84 \%(n=84)$ reported participating in religious services at least once a week, with $54 \%(n=54)$ of those attending services 1 to 2 times per week and $31 \%(n=31)$ attending services 3 or more times a week. Only $14 \%(n=14)$ of the sample reported attending religious services one or fewer times a month. Most participants were Baptist (33\%, $n=33)$, followed by Presbyterian $(24 \%, n=24)$, Methodist $(24 \%, n=24)$, Lutheran $(13 \%, n=13)$, Pentecostal $(5 \%, n=5)$, and Catholic $(1 \%, n=1)$. Ninety-six percent $(n=48)$ of the highly religious respondents preferred to work with a Christian counselor. Similarly, $77 \%(n=43)$ of the moderately religious participants preferred to work with a Christian counselor; $18 \%$ $(n=10)$ of that group were undecided.

Forty-one percent $(n=41)$ of the sample had previously participated in counseling, whereas $59 \%(n=59)$ had not. Of the participants who had previously participated in counseling, the majority attended 1 to 3 counseling sessions $(37 \%, n=15)$, others attended 4 to 6 sessions $(24 \%, n=10)$, and the minority of participants attended more than 12 sessions $(24 \%, n=10)$. Fifteen percent $(n=6)$ of the respondents who had previously participated in counseling attended 7 to 12 sessions. Of the participants who had previously attended counseling, $43 \%(n=18)$ had worked with a Christian counselor, $33 \%(n=14)$ had worked with a non-Christian counselor, and $24 \%(n=10)$ did not know whether the counselor was a Christian counselor. Of the 10 respondents who did not know whether the counselor was Christian, $80 \%(n=8)$ were moderately religious, and $20 \%(n=2)$ were highly religious.

\section{Instruments}

Shepherd Scale. The Shepherd Scale, developed by Bassettet al. (1981), was derived from "biblical principles of Christianity" to measure conservative, evangelical Christianity and to differentiate Christians from non-Christians. The scale has also been used in studies to identify high, moderate, and low levels of conservative Christianity (McCullough \& Worthington, 1995; Morrow et al., 1993). In the current study, the Shepherd Scale was used in this capacity. The 38 items of the scale are rated on a 4-point Likert-type scale, ranging from $1=$ not true to 4 =true. Examples include "I believe I have the personal presence of God in my life" and "I believe that everyone's life has been twisted by sin and that the only adequate remedy to this problem is Jesus Christ." Scores range from 38 to 152 , with higher total scores conveying a greater strength of evangelical Christian orientation. Bassett et al. reported a reliability coefficient Cronbach's alpha of .86 for the scale. Pecnik and Epperson (1985) reported a Cronbach's alpha of .94 for the instrument and a positive correlation of .71 between the scale and a self-reported measure of importance of religious beliefs.

Expectations About Counseling: Brief Form $(E A C-B)$. The Expectations About Counseling questionnaire was originally developed by Tinsley, Workman, 
and Kass (1980). It consisted of 135 items that were grouped into 18 expectancy subscales. In 1982, Tinsley revised the scale to its current form as the EAC-B. The EAC-B consists of 66 items that are rated on a 7-point Likerttype scale, ranging from $1=$ strongly disagree to $7=$ strongly agree. Participants respond to prompts of "I expect to..." and "I expect the counselor to..." The items are grouped into 18 expectancy subscales that cover five areas of expectations about counseling and are reported as mean item ratings. These five areas are (a) client attitudes and behaviors, (b) client characteristics, (c) counselor attitudes and behaviors, (d) counselor characteristics, and (e) characteristics of the process. The 18 expectancy subscales are Motivation, Openness, Responsibility, Acceptance, Confrontation, Directiveness, Empathy, Genuineness, Nurturance, Self-Disclosure, Attractiveness, Expertise, Tolerance, Trustworthiness, Concreteness, Immediacy, Outcome, and Realism. Tinsley reported a coefficient alpha of .923 for the EAC-B.

Behavior and Attitude Expectancies (BAE). The BAE (developed by the first author for use in this study) is a 24-item scale that was generated from the available literature to measure respondents' expectations of a non-Christian counselor regarding the display of attitudes that are sensitive to the beliefs and practices of Christians. A thorough review of the counseling literature revealed 24 behaviors and attitudes that are considered helpful when working with Christians in counseling. These include (a) using religious language and metaphors (Frame \& Williams, 1996; Georgia, 1994; Ingersol, 1994; Magaletta \& Swartz, 1995; Stander, Piercy, Mackinnon, \& Helmeke, 1994), (b) being familiar with different religious practices and beliefs (Bishop, 1992; Georgia, 1994), (c) using scripture in session and in homework assignments (Ball \& Goodyear, 1991; Bergin, 1988; Moon, Bailey, Willis, \& Kwasny, 1993; Worthington, 1990), (d) involving ministers in the therapeutic process (Ingersol, 1994), (e) integrating religion into treatment (Beutler, Crago, \& Arizmendi, 1986; Bishop, 1992; Georgia, 1994), (f) addressing religious issues in the counseling session (Bergin, 1988; Bishop, 1992; Worthington, 1990), (g) praying with clients in session (Ball \& Goodyear, 1991; Bergin, 1988; Moon et al., 1993; Worthington, 1990), (h) self-disclosing about personal religious beliefs (Bishop, 1992; G. A. Miller, 1992), (i) respecting religious autonomy (Bishop, 1992), (j) accepting religious beliefs and practices (Beutler et al., 1986; Bishop, 1992; Ingersol, 1994), and (k) having an open attitude toward religion (Beutler et al., 1986; Bishop, 1992).

On the basis of this review of the literature, these behaviors, along with Worthington and Scott's (1983) negative anticipations about counseling, were combined by the first author to create the BAE. The scale consists of 24 statements that are rated on a 7-point Likert-type scale, ranging from $1=$ strongly disagree to 7 = strongly agree. The items are prompted with "I expect the counselor to..." Examples of the statements include "Pray with me," "Have differing beliefs than I do," "Use scripture," and "Have an open attitude towards religion." For our study, the reliability for the religious behaviors items was determined at an alpha of .82, and an alpha of .73 was 
determined for the religious attitudes items. To further investigate the reliability of the BAE, a measure of internal consistency was calculated for each item of the measure. Each item was found to have an alpha of between .81 and .84 , suggesting that all items were important to the BAE.

Demographics. Participants were asked to provide information regarding their (a) age, (b) sex, (c) ethnicity, (d) participation in religious services, (e) past participation in counseling, (f) preference for Christian or non-Christian counseling, and (g) self-reported measures of importance of religious beliefs.

\section{Procedure}

We recruited participants for the study from seven Christian churches and three campus-based religious student organizations. Ministers of the churches and religious organizations signed a written permission form before participants were contacted to allow data to be collected at the sites. The first author administered the surveys in Bible classes and devotionals. A brief overview of the purposes of the study was provided, written instructions for completion of the surveys were read, and the participants were asked to voluntarily complete all instruments (the Shepherd Scale, EAC-B, BAE, and demographic information) at that time.

\section{Results}

Scores on the Shepherd Scale are used to measure respondents' level of conservative Christianity. The developers of the scale (Bassett et al., 1981) did not provide cutoff scores for classifying respondents as low, moderate, or highly conservative Christians; however, previous researchers (Guinee \& Tracey, 1997) have used median scores for grouping respondents according to the three classifications. After consulting with a statistician, we determined that using the median scores for the current sample of church attendees to separate them into moderately and highly religious groups was appropriate. For our sample, the median Shepherd Scale score was 135, with a range of 116 to 152 , suggesting that this population was committed to conservative Christian views. This finding was not a surprise because data were collected at churches from individuals who were involved in Sunday school classes or Bible studies. Because the Shepherd Scale scores were negatively skewed, the sample was split into two groups on the basis of the median score (135). Thus, participants who scored above the median were considered more "highly conservative," and individuals who scored below the median were considered more "moderately conservative." As an additional measure of participants' religious commitment, respondents were asked to respond to the statement, "I consider myself to be a highly religious person." Fifty-eight percent $(n=58)$ of the respondents agreed that this statement was "somewhat" true for them, whereas $29 \%(n=29)$ marked this statement as "very true" about themselves. In response to the statement, "My 
religious beliefs affect my decision making about my daily life," 95\% ( $n=95)$ of the respondents agreed, and $2 \%(n=2)$ responded with "neutral."

To address the first research question regarding the expectations of Christians (i.e., those categorized as moderately and highly conservative) for nonChristian counselors, a multivariate analysis of variance (MANOVA) was used to analyze the data. The results of the MANOVA showed a statistically significant main effect for level of conservatism, $F(2,19)=2.367, p<.01$; denomination, $F(2,19)=1.465, p<.01$; and previous counseling experience, $F(2,19)=1.721, p<.01$. The interaction effects of level of religiosity by denomination, $F(2,19)=1.069, p>.05$, and by previous participation in counseling, $F(2,19=.435, p>.05$, were not statistically significant. Also, the interaction effect of denomination by previous counseling experience was not statistically significant, $F(2,19)=.951, p>.05$. The three-way interaction was also not statistically significant, $F(2,19)=.993, p>.05$. Results of the MANOVA are presented in Table 1.

The results of a Tukey HSD post hoc test revealed differences for denomination on the EAC-B subscales. Pentecostal participants scored lower than did many participants from other denominations on 10 of the subscales (i.e., Motivation, Openness, Confrontation, Genuineness, Trustworthiness, Attractiveness, Concreteness, Immediacy, Outcome, and Expertise).

For the independent variable "having previously participated in counseling," seven subscales of the EAC-B were significant: (a) more client motivation (Motivation), $F(1,18)=8.774, p<.05,\left(M_{\text {yes }}=71.88, M_{\mathrm{no}}=68.62\right)$; (b) expected more confrontation (Confrontation), $F(1,18)=5.775, p<.05,\left(M_{\text {yes }}=5.08\right.$, $\left.M_{\mathrm{no}}=5.06\right) ;(\mathrm{c})$ expected more nurturance (Nurturance), $F(1,18)=6.768$, $p<.05,\left(M_{\text {yes }}=5.82, M_{\text {no }}=5.33\right)$; (d) view the counselors as more attractive (Attractiveness), $F(1,18)=5.494, p<.05,\left(M_{\text {yes }}=4.85, M_{n 0}=4.20\right) ;(\mathrm{e})$ expected the counselor to be more concrete (Concreteness), $F(1,18)=12.360, p<.05$, $\left(M_{\text {yes }}=5.81, M_{\mathrm{no}}=5.21\right) ;(\mathrm{f})$ expected the counselor to use more immediacy (Immediacy), $F(1,18)=12.995, p<.05,\left(M_{\mathrm{yes}}=5.62, M_{\mathrm{no}}=4.84\right)$; and $(\mathrm{g})$ expected a better outcome (Outcome), $F(1,18)=7.959, p<.05,\left(M_{\text {yes }}=5.70, M_{\mathrm{no}}=5.03\right)$.

\section{TABLE 1}

\section{Multivariate Analysis of Variance for Expectations About Counseling}

\begin{tabular}{lcc}
\hline Source & $d f$ & $F$ \\
\hline Levels of conservatism & 1 & $2.367^{\star *}$ \\
Denomination & 4 & $1.465^{\star \star}$ \\
Previous counseling & 1 & $1.721^{*}$ \\
Level of Religiosity $\times$ Denomination & 4 & 1.069 \\
Level of Religiosity $\times$ Previous Counseling & 1 & 0.435 \\
Denomination $\times$ Previous Counseling & 4 & 0.951 \\
Three-way interaction & 4 & 0.993 \\
Error & 19 & - \\
\hline${ }^{*} p<.10 .{ }^{* *} p<.01$. & &
\end{tabular}


To address the second research question regarding the expectations of Christians regarding the inclusion of religious behaviors in counseling by non-Christian counselors, a one-way analysis of variance (ANOVA) was run at the .05 alpha level. The results of the ANOVA were statistically significant, $F(1,83)=4.927, p=.029$. The mean scores for the Religious Behavior scale of the BAE revealed that the highly conservative group $(M=71.82$, $S D=19.17$ ) scored higher (i.e., expected more religious behavior) than did the moderately conservative group $(M=68.05, S D=14.17)$.

To address the final research question regarding the expectations of Christians regarding the inclusion of religiously supportive attitudes by a nonChristian counselor, a one-way ANOVA was run at the .05 alpha level. Results of the test were not statistically significant, $F(1,83)=1.858, p=.177$, suggesting that moderately and highly conservative Christians held the same expectations of the non-Christian counselor's attitude toward the clients' religious beliefs. Descriptive statistics for each question in the BAE scales are presented in Table 2.

\section{Discussion}

Previous research emphasized the impact of client expectations on the outcome of counseling (Tinsley et al., 1993; Tinsley et al., 1984; Tinsley \& Harris, 1976; Tinsley et al., 1994; Worthington, 1988; Yanico \& Hardin, 1985). To extend and clarify the contradictory results of previous studies of the expectations of conservative Christians about counseling, we examined Christians' expectations of a non-Christian counselor. When we compared the expectations of Christians with moderate and high levels of conservatism, we found that when a traditional measure of expectations was used, there were significant differences between the two groups. In addition, there were significant differences between moderately and highly conservative participants in terms of the amount of in-session religious behaviors expected from the counselor (e.g., use of religious language, prayer, scripture), with the highly conservative group expecting significantly more in-session religious behaviors than did the moderately religious group. This finding is consistent with Worthington's (1988) description of the values of highly religious individuals, which emphasize the importance of scriptures and the power of religious leaders and religious group norms in every area of their lives. In contrast, the moderately conservative Christians did not expect the counselor to self-disclose about his or her religious beliefs. Although the general self-disclosure literature indicates that clients want their counselor to self-disclose (Goldstein, 1994; Hill, 1992), our finding may suggest that religion is less a topic of concern for moderately conservative Christians than it is for highly conservative Christians when it comes to counseling. Similarly, moderately conservative Christians were less likely than were conservative participants to expect the counselor to involve their ministers in the counseling process. 


\section{Descriptive Statistics for the Behavior and Attitude Expectancies (BAE) Scales}

\begin{tabular}{|c|c|c|c|}
\hline BAE Item & $\boldsymbol{M}$ & $M d n$ & Mode \\
\hline Use religious language & 3.29 & 3 & 1 \\
\hline Use religious metaphors & 3.25 & 3 & 1 \\
\hline Pray with me & 3.24 & 3 & 1 \\
\hline Have different religious beliefs as I do & 3.45 & 3 & 1 \\
\hline Challenge my religious beliefs & 2.34 & 1 & 1 \\
\hline $\begin{array}{l}\text { Focus on my spiritual growth } \\
\text { Be familiar with my religious practices and }\end{array}$ & 3.21 & 3 & 1 \\
\hline beliefs & 4.04 & 4 & 7 \\
\hline Ignore my religious beliefs & 1.99 & 1 & 1 \\
\hline Use scripture & 2.80 & 2 & 1 \\
\hline Refer me to clergy for religious issues & 4.59 & 5 & 7 \\
\hline $\begin{array}{l}\text { Address religious issues in counseling } \\
\text { Treat my religious beliefs and experiences }\end{array}$ & 3.25 & 3 & 1 \\
\hline as a problem & 1.77 & 1 & 1 \\
\hline Give homework using scripture & 2.18 & 1 & 1 \\
\hline Involve my minister/pastor in counseling & 3.58 & 4 & 1 \\
\hline $\begin{array}{l}\text { Undermine my religious beliefs } \\
\text { Self-disclose about his or her own religious }\end{array}$ & 1.57 & 1 & $i$ \\
\hline beliefs & 2.29 & 2 & 1 \\
\hline $\begin{array}{l}\text { Integrate religion into my treatment } \\
\text { Recommend behaviors or solutions that I }\end{array}$ & 3.40 & 3 & 1 \\
\hline consider immoral & 1.58 & 1 & 1 \\
\hline $\begin{array}{l}\text { Respect my religious autonomy } \\
\text { Be accepting of my religious beliefs and }\end{array}$ & 6.00 & 7 & 7 \\
\hline practices & 5.75 & 6 & 7 \\
\hline Have an open attitude towards religion & 5.44 & 6 & 7 \\
\hline $\begin{array}{l}\text { Have a negative attitude towards religion } \\
\text { Assume that I share values of non- }\end{array}$ & 1.70 & 1 & 1 \\
\hline $\begin{array}{l}\text { religious people } \\
\text { Doubt the usefulness of learning from God }\end{array}$ & 2.36 & 1 & 1 \\
\hline through prayer and scripture & 1.93 & 1 & 1 \\
\hline
\end{tabular}

Another interesting finding of this study was related to the effect of Christians' previous participation in counseling on their expectations of the counselor. Participants who had previous counseling experience consistently reported higher mean expectancy scores (i.e., more favorable expectations of counseling) than did participants who had not previously received counseling. Specifically, these individuals expected the counselor to use more confrontation and to be more nurturing, more attractive, more concrete, and more immediate. Similarly, a more favorable outcome for the counseling process was expected. This finding may suggest that increased education about, awareness of, and exposure to the counseling process could help to improve conservative Christians' positive expectations of the counseling process.

A final noteworthy finding of the study was related to participants' expectations of how counselors would handle participants' religious beliefs and values. Both the highly and moderately conservative Christians expected 
the counselor to respect their religious autonomy, to be accepting of their religious beliefs and practices, and to have an open attitude toward religion. This result does not seem to support the negative anticipations of Christians for non-Christian counselors described by Worthington and Scott (1983). In fact, all items on the BAE that were related to Worthington and Scott's negative anticipations received extremely positive scores (adjusting for reverse scoring). However, the impact of the role of the sample's counseling savvy (i.e., approximately $40 \%$ of the respondents had received counseling) on this finding is not known. Nevertheless, the majority of participants (those who had and had not received counseling) reported that they would prefer to work with a Christian counselor, which is similar to the findings of previous researchers (Guinee \& Tracey, 1997).

\section{Limitations}

To properly interpret the results of the current study, several limitations must be considered. Our sample had little ethnic diversity $(98 \%$ of participants were Caucasian); therefore, it is not known how members of other racial and ethnic groups would compare with the participants in our study. In addition, the sample comprised individuals from the mid-South region of the United States, which limits generalizability to other regions of the country. Also, asking people to speculate about their expectations of counseling without a specific context (i.e., type of problem) is a drawback of the analog design used in the study. Although the literature reports that Christians with negative expectations would hesitate to seek counseling, it is not known what Christians would do when actually faced with a serious life problem. A final limitation of the study is related the use of the $B A E$, a new instrument that was used for the first time in this investigation. Therefore, it is important to remain very cautious about the current findings until future research either supports or refutes our results.

\section{Implications for Counseling}

In general, the results of our study offer several interesting implications for counseling practice. First, the results suggest that counselors who are not working in religious settings may want to consider the strength of conservatism among their Christian clients with regard to in-session religious behaviors the client may desire. Specifically, it seems appropriate for counselors to discuss with conservative Christian clients the religious behaviors, if any, the client expects to be present in counseling and to work to find ways that are comfortable for both the counselor and client to address these expectations. Second, it is possible that both moderately and highly conservative Christians might expect even non-Christian counselors to have open and positive attitudes toward the client's beliefs, even if the counselor does not overtly address religion or attempt to include religious behaviors in 
counseling. Therefore, it may be important for non-Christian and perhaps more liberal Christian counselors to seek to understand and appreciate the conservative Christian perspective. Third, it may be helpful for counselors to determine whether conservative Christian clients have received previous counseling because it is possible that individuals who have received counseling will be more comfortable with the counseling process than those who have not. A final clinical implication of the findings is that practitioners need to evaluate their level of skill and comfort in working with highly conservative Christian clients. Of course, there are important ethical considerations when working with highly religious individuals that require counselors to be honest with themselves and their clients about decisions regarding whether to include religious behaviors in counseling as well as how to be respectful of client beliefs.

\section{Conclusion}

The results of this study indicated that the more highly conservative Christians tended to expect secular counselors to include some religious behaviors in the counseling process. Furthermore, it seemed that both moderately and highly conservative Christians expected non-Christian counselors to display attitudes that were respectful of Christian beliefs. To extend this line of research, future researchers could investigate the expectations of Christians from more diverse racial and ethnic populations. In addition, research is needed to investigate the impact on counseling outcomes when conservative Christian's expectations for counseling are either met or not met. Finally, studies are needed to determine the types of concerns for which conservative Christians would turn to a minister or other religious figure versus a secular counselor.

\section{References}

Ball, R. A., \& Goodyear, R. K. (1991). Self-reported professional practices of Christian psychotherapists. Journal of Psychology and Christianity, 10, 144-153.

Bassett, R., Sadler, R. D., Kobischen, E. E., Skiff, D. M., Merrill, I. J., Atwater, B. J., et al. (1981). The Shepherd Scale: Separating the sheep from the goats. Journal of Psychology and
Theology, 9, 335-351.

Belaire, C., \& Young, J.S. (2000). Influences of spirituality on counselor selection. Counseling and Values, 44, 189-197. Bergin, A. E. (1980). Psychotherapy and religious values. Journal of Consulting and Counseling
Psychology, 48, 95-105.

Bergin, A. E. (1988). Three contributions of a spiritual perspective to counseling psychotherapy and behavior change. Counseling and Values, 33, 21-31.

Bergin, A. E. (1991). Values and religious issues in psychotherapy and mental health. American Psychologist, 46, 394-403. Bergin, A. E., \& Jensen, J. P. (1990). Religiosity of psychotherapists: A national survey. $P_{s y-}$
chotherapy, 27, 3 7.

Beutler, L. E., Crago, M., \& Arizmendi, T. G. (1986). Therapist variables in psychotherapy process and outcome. In S. Garfield \& A. E. Bergin (Eds.), Handbook of psychotherapy and behavior change (3rd ed., pp. 257-310). New York: Wiley. 
Bishop, D. R. (1992). Religious values as cross-cultural issues in counseling. Connseling and Values, 36, 179-191.

Frame, M. W., \& Williams, C. B. (1996). Counseling African Americans: Integrating spirituality in therapy. Counseling and Values, $41,16-28$.

Georgia, R. T. (1994). Preparing to counsel clients of different religious backgrounds: A phenomenological approach. Counseling and Values, 38, 143-151.

Godwin, T. C., \& Crouch, J. G. (1989). Subjects' religious orientation, counselor's orientation and skill, and expectations for counseling. Journal of Psychology and Theology, 17, 284-292.

Goldstein, E. G. (1994). Self-disclosure in treatment: What therapists do and don't talk about. Clinical Social Work Journal, 22, 417-433.

Grimm, D. W. (1994). Therapists' spiritual and religious values in psychotherapy. Countseling and Values, 38, 154-164.

Guinee, J. P., \& Tracey, T. J. G. (1997). Effects of religiosity and problem type on counselor description ratings. Journal of Counseling $\mathcal{E}$ Development, 76, 65-73.

Hill, C. E. (1992). Research on therapists' techniques in brief individual therapy: Implica-

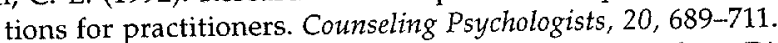

Ingersol, R. E. (1994). Spirituality, religion, and counseling: Dimensions and relationships. Counseling and Values, 38, 98-111.

Keating, A. M., \& Fretz, B. R. (1990). Christians' anticipations about counselors in response to counselor descriptions. Journal of Counseling Psychology, 37, 293-296.

King, R. R. (1978). Evangelical Christians and professional counseling: A conflict of values. Journal of Psychology and Theology, 6, 276-281.

Kroll, J., \& Sheehan, W. (1989). Religious beliefs and practices among 52 psychiatric inpatients in Minnesota. American Journal of Psychiatry, 146, 67-72.

Larson, D. B., Donahue, M. J., Lyons, J. S., \& Benson, P. L. (1989). Religious affiliations in mental health research samples as compared with national samples. Journal of Nervous and Mental Disease, 177, 109-111.

Lovinger, R. J. (1979). Therapeutic strategies with "religious" resistances. Psychotherapy: Theory, Research and Practice, 16, 419-427.

Magaletta, P. R., \& Swartz, C. (1995, August). From theory to practice: Addressing religious issues in the family. Paper presented at the annual meeting of the American Psychological Association, New York.

McCullough, M. E., \& Worthington, E. L., Jr. (1995). College students' perceptions of a psychotherapist's treatment of a religious issue: Partial replication and extension. Journal of Counseling $\mathcal{E}$ Development, 73, 626-634.

Miller, G. A. (1992). Integrating religion and psychology in therapy. Counseling and Values, 36, 112-122.

Miller, J. P., \& Eells, G. T. (1998). The effects of degree of religiosity on attitudes toward seeking professional counseling. Journal of Psychology and Christianity, 17, 248-256.

Moon, G. W., Bailey, J. W., Willis, D. E., \& Kwasny, J. C. (1993). Self-reported use of Christian spiritual guidance techniques by Christian psychotherapists, pastoral counselors, and spiritual directors. Journal of Psychology and Christianity, 12, 24-37.

Morrow, D., Worthington, E. L., Jr., \& McCullough, M. E. (1993). Observers' perceptions of a counselor's treatment of a religious issue. Journal of Counseling $\&$ Development, 71 , 452-456.

Pate, R. H., Jr., \& Bondi, A. M. (1992). Religious beliefs and practice: An integral aspect of multicultural awareness. Counselor Education and Supervision, 32, 108-115.

Pecnik, J. A., \& Epperson, D. L. (1985). Analogue study of expectations for Christian and traditional counseling. Journal of Counseling Psychology, 32, 127-130.

Quackenbos, S., Privette, G., \& Klentz, B. (1985). Psychotherapy: Sacred or Secular? Journal of Counseling and Development, 63, 290-293.

Stander, V., Piercy, F. P., Mackinnon, D., \& Helmeke, K. (1994). Spirituality, religion and family therapy: Competing or complementary worlds? The American Journal of Family Therapy, $22,27-41$. 
Tinsley, H. E. A. (1982). Expectations About Counseling: Brief Form. Unpublished test manual, University of Florida, Gainesville.

Tinsley, H. E. A., Bowman, S. L., \& Barich, A. W. (1993). Counseling psychologists' perceptions of the occurrence and effects of unrealistic expectations about counseling and psychotherapy among their clients. Journal of Counseling Psychology, 40, 46-52.

Tinsley, H. E. A., Brown, M. T., De St. Aubin, T. M., \& Lucek, J. (1984). Relation between expectancies for a helping relationship and tendency to seek help from a campus help provider. Journal of Counseling Psychology, 31, 149-160.

Tinsley, H. E. A., \& Harris, D. J. (1976). Client expectations for counseling. Journal of Counseling Psychology, 23, 173-177.

Tinsley, H. E. A., Tokar, D. M., \& Helwig, S. E. (1994). Client expectations about counseling and involvement during career counseling. The Career Development Quarterly, 42, 326-336.

Tinsley, H. E. A., Workman, K. R., \& Kass, R. A. (1980). Factor analysis of the domain of client expectancies about counseling. Journal of Counseling Psychology, 27, 561-570.

Worthington, E. L., Jr. (1988). Understanding the values of religious clients: A model and its application to counseling. Journal of Counseling Psychology, 33, 166-174.

Worthington, E. L., Jr. (1990). Marriage counseling: A Christian approach to counseling couples. Counseling and Values, 35, 3-23.

Worthington, E. L., \& Gascoyne, S. R. (1985). Preferences of Christians and non-Christians for five Christian counselors' treatment plans: A partial replication and extension. Journal of Psychology and Theology, 13, 29-41.

Worthington, E. L., \& Scott, G. G. (1983). Goal selection for counseling with potentially religious clients by professional and student counselors in explicitly Christian or secular settings. Yournal of Psychology and Theology, 11, 318-329.

Yanico, B. J., \& Hardin, S. I. (1985). Relation of type of problem and expectations of counselor knowledge and understanding to students' gender preferences for counselors. Journal of Counseling Psychology, 32, 197-205. 